\title{
Men Without Fingers, Men Without Toes
}

\section{ABSTRACT}

What happens once the rogue rides off into the sunset? This crossgenre essay considers the figure of the rogue's decline and gradual dismemberment in the face of the pressures of the world. Beginning with the "rogue" digits and other body parts lost by the men who surrounded him in his youth-especially his grandfather-Dobson considers the costs of labour and poverty in rural environments. For him, the rogue is one who falls somehow outside of cultural, social, and political normsthe one who has decided to step outside of the establishment, outside of the corrupt élites and their highfalutin ways. To do so comes at a cost. Turning to the life of writer George Ryga and to the poetry and fiction of Patrick Lane, this essay examines the real, physical, material, and social costs of transgression across multiple works linked to rural environments in Alberta and British Columbia. The essay shows the ways in which very real forms of violence discipline the rogue, pushing the rogue back into submission or out of mind, back into the shadowy past from whence the rogue first came. Resisting nostalgia while evincing sympathy, this essay delves into what is at stake for one who would become a rogue.

Keywords: Canadian literature, masculinity, violence, labour, alienation. 
I circle back to the bridge, that bridge that I crossed again and again as a child, and this time consider it through the lens of the rogue. What does it mean to be a rogue, or to go rogue?

Roguishness can be variously defined. It seems to attach to masculinity - though it need not—and it also seems to have something to do with those who fall somehow outside of cultural, social, and political norms. The rogue is the one who has decided to step outside of the establishment, outside of the corrupt élites and their highfalutin ways. The cowboy is a rogue; the outlaw is a rogue; Billy the Kid - a rogue. Kit Carson-a rogue.

To go rogue, too, is to go missing-to be Absent Without Leave, AWOL, to step into the shadows. It is easy to romanticize the rogue, like the Western hero who comes to town out of a shadowy past. The hero will re-right the "proper" order of the town, putting the villains to rest, and then, roguishly, will disappear back into the horizon from whence that hero first came. What happens once the rogue rides off into the sunset? It's seldom that the sunset equates with a happily ever after, after all.

At that moment, to me, the rogue becomes interesting. I grew up around many men whose digits had, for lack of a finer term for it, gone rogue. Throughout childhood, there they were: men missing fingers, missing toes, missing teeth. They were missing bits of their bodies and smiling all the same. These were rogues, living in the afterglow of the Western's sunset endings. The women around whom I grew up were often missing parts of their bodies as well, but more often in connection with the medical establishment of the day. But that is a topic for another time, and it is perhaps one that others might be able to speak to better than I ever could.

So take a former farm hand whom I often used to see as a child. He was missing the ring finger on one of his hands. He loved to scare us children with his missing digit, the absence providing a shock every time that I saw him. Late in life, when he lost his leg to complications from diabetes, even though I could tell that he was suffering, he joked about that too, and he did so from behind a cloud of smoke and the stubble of a two-day beard.

Or take my late grandfather's friend, a farmer who had lost much of one hand in a threshing accident. Clutching a cup of coffee in his good hand, he would laugh over some ridiculous nothing that the cattle had done until his asthma got the best of him. He never hid his mangled hand, yet neither did he flaunt it. His flannel and denim had bits of straw clinging to it, and his ball caps sat high on his thinning pate.

Everywhere I turned, there was another roguish character, laughing through the disfigurations of labour. There, the end of a finger had been lost in a slammed truck door-there, a chunk of skin had been flayed off 
of a knee-there, a finger was shorter now, in the middle, after having been cut off accidentally by a mitre saw, and then reattached, badly, by the bone-saw.

The world of labour asks that we-at times literally-sacrifice our bodies to the toil. Surplus labour, surplus digits. I have long thought over it, as I watched all of those aging rogues, living in the afterlives of a onceheroic moment, undergoing hip and knee replacements, rotator cuff surgeries, and spinal fusions. I think of the final pain that my grandfather endured as they removed what was supposedly the largest tumour ever taken out of an Albertan-one that was about the size of a turkey-as he stepped toward his final exit.

I also think of my grandfather's coffee cup, festooned with the mug of a grizzled old cowboy. The cup read: "Neither drouth, nor rain, nor hail, nor blizzard / will quell the joy-juice in this ol' gizzard!” And it was true. I was particularly taken by the spelling of drought, and the idea that my grandfather, and perhaps all of the rogues around me (in a way that set them apart), also had gizzards, the stones therein providing the gravely timbre of their voices.

All of this takes place in northern Alberta, in and around the town of Athabasca. A young, soon-to-be writer from a farm north of town, a young George Ryga, also had some of his digits go rogue on him, way back on a cold winter's day in 1951. George Ryga would later write the controversial play The Ecstasy of Rita Joe, a play that helped to bring Indigenous issues to light for settler audiences in the 1960s. He wrote novels, plays, and radio scripts for most of his life after leaving the hardscrabble north. The Ryga farm was just up the road from the one on the maternal side of my family.

The story goes that he lost his fingers in a concrete-pouring accident while serving as a construction worker on the bridge that would soon cross the Athabasca River, but I never thought of it quite like that. I always imagined his fingers, instead, as being stuck in the bridge, as holding the whole works in place, heroically maintaining their grip long after the death of their former owner. George Ryga has passed on, and his novels set in the region of his youth are too often forgotten, but the bridge stands. I liked, for a long time, to imagine that it does so only because of those missing fingers, stuck between two spans, dextrously holding it all in place.

Instead, I learned from reading his biography that the story was a little bit different. Here is how his biographer describes it:

One day in mid-March, with the temperature at minus forty, he was required to work on a large crane-operated container that was filled with concrete near the shore, then hoisted out over the river to the caisson footings that were the main supports of the bridge. Ryga's job was to 
ride atop this huge bucket and unlock manually a tripping device to dump the load of concrete. A chain ran from the lid below to a pulley above where Ryga stood. With the load suddenly dropped, the bucket lurched upwards, the chain raced towards the pulley-and Ryga's hand was caught. (Hoffman 53)

Ryga would later write a novel-unpublished and now in the University of Calgary archives-called The Bridge, and the event left a mark on him beyond the literal one. Ryga hides his absent digits in pretty well every subsequent photo of himself that I have seen-his right hand is usually out of view. He would go on to maintain fervent Marxist commitments and to write, not always popularly, from the interior of British Columbia where he lived for much of his life. There remains a prize named for him that is awarded to a writer who demonstrates strong "social awareness" in a book.

Digits, missing digits, and the labours that pull bodies apart: these show up, again and again, throughout the lives of those around me.

A few years ago, I tried to write a very different, much more hoity-toity "academic" version of this story, focusing on the missing digits that show up with regularity in the work of the recently deceased British Columbia writer Patrick Lane. While I thought that I was onto something there, when I delivered it as a talk, one audience member strongly disagreed with my take on labour and the afterlife of the rogue, arguing instead that these symbols of sacrifice could or should be read as allegories of Jesus Christ, or something to that effect. Perhaps we were both right-or both wrong. But the rogues whom I have known might have been most likely to use the Lord's name when it was in vain, during an accident-they were seldom regular church-going men. I still see that rogue digit as a price paid to a too often uncaring world of work that will extract from you every possible price-and then still repossess the farm.

Patrick Lane's work, George Woodcock notes, takes "its roots in Canadian working-class life," but it expands from there (8). Or, as Dermot McCarthy puts it, "Patrick Lane's poetry often seems to be ... the flesh seeking an escape to spirit through words, but always failing, falling back, exhausted, frustrated, and ashamed" (52). The flesh, indeed, seems to lock in the spirit; I will go further to suggest that the world of work in Lane's writing alienates both the flesh and the spirit. While there is a surprising number of examples of severed or deadened body parts in Lane's writing, I will focus on a few ones that are, I think, important to understanding his fascination with this motif. These will, in turn, allow me to link back to the rogue, and how the rogue lives on in the afterglow of aging, fumbling past glory and failure. 
This motif, I think, actually contradicts Lane's best-known poetic statement of intent, "To the Outlaw," from 1971, in which he affirms a Nietzschean vision of the poet as someone who "has no place within the law" because she or he is "the outlaw surging beyond the only freedom $[\mathrm{s} /]$ he knows" (211). The severed hand, it seems to me, suggests that the opposite might be true. It shows us that the rogue has neither origins nor originals-no Nietzschean outlaws who blaze their own trails-but, rather, an experience of alienation and failure that comes from the world of work and struggle.

The productive act, the act of work, exists either literally or metaphorically in the hand, but what happens when the hand no longer functions or exists? Can you be a farm hand without hands to farm with? Hands, of course, also do the physical work of writing, either metaphorically or literally, and may not be separable from either the creative act or the worker's toil, too. My first example from Lane's work is the poem "After," which appears first in Lane's 1973 chapbook Passing Into Storm. It appears again in the 1978 book Poems Nere and Selected, a book that collects much of Lane's early work published in small press runs. The poem appears as well in the 1987 collection Selected Poems. It is about a man who has lost the sensation in one of his arms. It reads as follows:

\author{
After the machine on the gypo show \\ caught his arm in its mouth \\ and chewed the nerves dead \\ from elbow to finger-tips \\ he sat in the bar \\ telling stories for drinks \\ His best the one about \\ how he'd lost the use of his arm \\ changing it every other day \\ until he ran out of variations \\ and no one would listen to him \\ the arm getting in his way \\ bumping into things \\ and hanging useless \\ until the only way \\ he had of getting a drink \\ was to lay the dead piece of meat \\ across the table \\ and stick pins in it \\ saying: \\ It doesn't hurt at all
}


men laughing

and buying him a drink

for every pin he could hammer in

with his empty glass. (Lane, Passing Into Storm n.pag.)

This poem, in its violence, both self-inflicted and shared, as well as its emphasis on emptiness - the emptied glass emphasizing a spiritual emptiness as well—could be said to be typical of Lane's earlier work. The "gypo show" - a slang term referring to a small logging operationreinforces Lane's concern with workers. The poem is, certainly, in its raw, minimal, and factual descriptions of the man's life, a harsh, vivid poem.

At first read, this poem connects to a wide range of works that focus on the deadened or fragmented body. Possible links would include texts such as Dorothy Livesay's "Lament: For J.F.B.L.," for her father John Frederick Bligh Livesay, in which she notes, in particular, her father's dead hands. Or we could link the poem to the key smear of white paint on the hand of the corpse of John in Sinclair Ross's "The Painted Door." Or we might invoke the one-armed restauranteur in Irene Baird's Waste Heritage. Or this image might connect-indeed it seems more readily to connectto the breakdown of the body that is so prevalent in Margaret Atwood's writing, such as the novel Surfacing, published a year before Lane's poem, in which Atwood's unnamed protagonist notes that she feels as though she is "nothing but a head, or no, something minor like a severed thumb; numb" (108). This context seems to account for one important aspect of Lane's version of this numbness. For Atwood, this severing is primarily linguistic in nature. It is "language," her narrator notes, that "divides us into fragments"; she wants, instead, "to be whole" (146), and she rejects language as a result. This language is patriarchal in nature; it is an oppressive representational mechanism that limits the range and possibility of the body, restricting it, or, worse, chopping it up according to sexist norms. Think, for instance, of the woman-shaped cake in Atwood's 1969 novel The Edible Woman, and the ways in which patriarchal culture, in much of Atwood's early writing, divides the self from the body.

Lane's vision of dead, numb, and severed hands and limbs, it seems, can be partly explained thinking about the body in this way. The linguistic and metaphorical dimensions of writing are, of course, important to the work of storytelling. After the worker of his poem loses the use of his arm, he is able to stick pins in it for drinks. He is also able to substitute his role as a storyteller for his former work in the logging camps, though his financial returns seem to be much diminished. These roles can't be separated: he must tell, over and over, and with increasing variations, the 
story of his injury, of damaging his arm. So too, it seems from reading his work over time, must Lane tell, again and again, the story of the severed hand, each time with new variations. The hands work to beget the lucre that allows them to continue to work another day. No hands, no lucre. Value, in other words, resides in the hands and, by extension, in the body. When the body is fragmented, meaning is lost.

This point, however, needs to be guided by a reminder of how very masculine this representation of the worker is, and by recognizing how the ideal of the complete body that we find in Lane's works is also metaphysical. Doing so through my next example will connect this poetry to, as critic Adam Carter puts it, "Lane’s overlapping concerns with struggle, violence, disempowerment, class, and history" (1).

Machinery and work appear again in this second key example, the poem "Just Living." This poem first appears in book form in The Measure in 1980, is reprinted in the 1987 collection Selected Poems, and again in the 1997 collection Selected Poems 1977-1997. The short story "Mill-Cry," in Lane's book How Do You Spell Beautiful? relates a parallel yet different incident. Lane's penchant for vivid, gory, yet factual description is again abundantly displayed in "Just Living." In its opening, Lane specifies, though, that his writing "isn't just violence," but, rather, is "just another story I no longer know / the truth of" (Lane, Selected Poems 1977-1997 22). The meat of this poem occurs in the following stanza:

We were five hours over mountain roads, the tourniquet wet red and him in the seat lifting the stump of his arm each mile looking by the glow of the dash-board lights.

Jesus. he kept saying between cigarettes.

In the pink ice-cream bucket between us the severed hand sloshed in the melting ice.

He never looked at that.

And then the usual madness, the nurse wanting his name and birthdate, demanding his wallet's proof until I lifted his sleeve and showed her. He grinned at that. The sight of those veins and tendons made her turn away. The doctors got him then. I asked one if he could use the hand but he said it was probably dead. Too many hours and, anyway, they couldn't put it back. (22)

Although the nurse turns away, as does the man who has lost his hand, the speaker never shies away from the details of the severed hand, the veins, 
and the tendons. The contrast between the bureaucratic hospital and the fact of the severing is highlighted, and the poem goes on to describe "the saw and the flesh still / hanging from the teeth" that removed the hand (22). The saw is not even washed; it will, by itself, "cook" off the remnants (22). The speaker of the poem is left with the worker's severed hand, now that it's been deemed useless. He wonders what to do with it. Eventually, he throws it off a bridge. The final, painful irony occurs at the end of the poem, with the outcome for the man who lost his hand:

Him? Oh, he came back. They'd healed him up.

His wife and kids had left by then.

Gone off with the trim-saw-man to Edmonton.

He hung around for a few days

but there was no work for a man

with a stump. And Claude, the boss,

didn't want him there. You can see why. (24)

This final turn, in which the man loses everything, points to the crux of my concern, in that his value seems to have consisted entirely in his hands, in his having hands. Once one is gone, his value diminishes, he loses his wife, and he is quietly shunned not merely by the boss, Claude, but also by the nonchalant speaker of the poem and, by extension, the reader, the "you" who "can see why" it was appropriate for him to be sent on his way. The afterlife of the rogue, it seems, is likely to be a lonely one.

It seems, indeed, to be a deeply masculine valuing of the body as a complete entity that leads to how Lane thinks about work. In the absence of the complete body, value trickles away. The original self no longer exists, and the solution is departure, exile, or death. Such a structure of alienation is something that I see in other texts, such as bpNichol's Selected Organs, when, in the poem "The Tonsils," Nichol notes that he misses his tonsils and also states that their removal marked his "first real lesson in having no attachments" (230). Severing marks, in other words, an entry into being an individual, being alone, and, even though Nichol feels in the poem that he is being paranoid, the possibility exists that other pieces of his body and self can be taken, too.

But an even more immediate link is to Earle Birney's poem "David." This very well known and often anthologized poem records the narrator Bob and his friend David's perilous mountain climbing exploits. This poem seems to place a value on the body as a "complete" thing too. At the crux of the poem, the narrator stumbles as he and David ascend an unmapped crag that David dubs "the Finger." David, reaching back to help the narrator, loses his footing and falls off the mountainside. When the 
narrator reaches David, still alive but badly injured, he swabs his "shredded hands" and observes his body, crushed against the rock. After the speaker asks David to summon his strength for a rescue operation, David answers "For what? A wheelchair?" and asks the narrator to push him over the adjoining drop, a fall of six hundred feet that will make sure that he's dead (58). The narrator, reluctantly, pushes David over. While the poem rightly displeases critics because of its focus on being able-bodied, the violence seems primarily to reiterate the importance of the vitality and virility of the body. When the body's whole self is challenged, the solution-to David, anyhow-seems to be death. In the disruption of wholeness, in other words, the only apparent alternative is absence. The reality is of course otherwise, but black or white thinking puts that fragmented body of the rogue into unknown territory.

It is worth noting that Lane appears to have been particularly influenced by Birney. In a poem entitled "For Earle Birney," he focuses, again, on hands. Lane, addressing Birney, states the following:

You wrote me back in 62 and told me

To keep writing. I was up north, a First-Aid-Man in a nowhere

Milltown, nursing the dregs of cheap whiskey, tapping out

Poems about bears at burning barrels, a cougar at the door,

A man with his hand cut off, ordinary things in the tired nights

When my children slept and my wife had given up on me.

The reference is surely to the poem "Just Living," as well as some of his other early work. The focus for Lane remains the body in its severed and broken forms, which he lists among the world of "ordinary things" that he then experienced. This violence is ordinary, he suggests, yet also noteworthy-noteworthy enough to constitute a narrative poem-and noteworthy enough to be among the key events that are retold in Lane's lamentation for the body, for what is left of the body in the world of work. Lane's is a lamentation of the body in fragments. The body, however, is rarely, if ever, whole.

If we want to psychologize Lane's fixation on hands, their disabling, and their severing - and if we want to trace them back, however problematically, to the author-it is useful to look, as I would like to do for my third example, at his 2004 book There Is a Season: A Memoir. Lane's memoir is a dense, at times viciously violent book that pairs his narratives about his past with his then present-day experiences of his quiet, meditative garden on Vancouver Island. It reveals and documents the tortured artist and his flaws, and recounts, importantly for this piece, Lane's experience of his time as a first-aid worker as follows: 
I still hear the cries of the woman whose child I delivered, the man I drove out to Kamloops, his mangled hand in an ice-cream bucket between us packed in cracked ice from the river. I worked my days, slept my fitful sleeps, got drunk with my wife every Friday and Saturday night, played with my children as I could, and in the rare moments of dark while my family slept I sat at the kitchen table, drank Seagrams 83 I'd stolen from the boss's stock, and wrote the poems that began my life as a writer.... We were leading what I thought was an ordinary life. Even as I wrote my first poems, I had no notion that it would lead to a life's work. Poetry allowed me an escape. It let me enter an imagined world with its ordered reality a thing I could control. (187-88)

The poem "Just Living," then, as well as "For Earle Birney," seem to report an event that Lane witnessed in his early days in the bush with his first wife. Particularly important to this instance of the severed hand, too, is that it leads directly to a consideration of poetry. This severing, which occurs in the context of industrial labour, leads somehow quite directly, though unexpectedly, to the life of writing in which Lane has engaged himself. This close link between industry and writing, I want to suggest with this example, shows how the two forms of work are not, at least metaphorically, all that different, and shows that the body, the working body, is necessarily fragmented, alienated, and broken. Forestry work leads to the alienation of the worker, best glimpsed when the worker loses his hand and can therefore no longer exist in the workforce. The work of poetry is also an exile, or an "escape" as Lane puts it, a distance-taking from the world around him, and, he discovers, a source of alienation from the world that he has known.

By way of a conclusion, I would like to circle back to the shadowy figure of the rogue with which I opened. I find the rogue, too, to be instructive for understanding how poetry and the creative process can be a labour of alienation from the self and the body in much the same way as physical work-at least at a metaphoric level. I'll do so through a final, though minor, example in Lane's writing, because the trope of the disabled or severed hand returns, yet again, in his 2008 novel Red Dog, Red Dog. This novel continues many of Lane's ongoing themes, and contains a back and forth between its sensual, violent descriptions of the interior of British Columbia and early poems like his often-anthologized "Albino Pheasants."

The novel follows the lives of the Stark family, especially brothers Tom and Eddy. Eddy, a heroin-addicted ex-convict, runs up and down the Okanagan in search of something ineffable, creating havoc and ruin behind him that his brother, Tom, cleans up. At one point, Eddy and his friend Harry go to an old man's house in order to rob him, and end up killing him. Tom goes to the house in order to dispose of the body and, while "going up 
the steps, he tripped on a sprung plank and fell, his left hand skidding on the boards, a nail-head ripping the skin of his palm" (159). The torn palm, it seems to me now, absolutely invites us to look at the book as being about sacrifice, the injury a form of stigmata. In the scene that follows, Tom suppresses the pain and takes care of the corpse. In the following scene, however, Tom is depicted back at work, in a local lumberyard stacking two-by-fours. When a hand is injured, its impact on work is never far behind. Later, Tom is asked what happened to his hand and he claims that he had "an accident" with a chisel (222). The novel, beyond this part of the story, abounds with partial, disabled bodies: Tom's love interest Marilyn has a bad eye, and readers are told that Tom and Eddy's father once left a man with "a crushed hand" after an argument (114). The body, working and scraping out a living in the harsh B.C. interior, fragments, comes apart, and collides with other bodies. The results in Lane's work are rarely pretty as people and animals fight over the scraps of life that are afforded to them in an open-ended rush to colonize the land.

Bodies are routinely dismembered in Patrick Lane's work, allowing him to connect his writing to a broad network of Canadian literature, but also allowing us to consider the question of where value resides. Hands do not simply generate value, they are themselves reservoirs of potential value and are themselves valuable. While, on the one hand, this idea is selfevident-I value my hands, as I do my person-on the other, this equation in Lane's poetry and prose means that hands are also inseparable from money. Labour generates value, but labour resides in the hands. Hands are therefore valuable and are therefore part of the exchange process.

This set up is, at least in Lane's writing, not just part of the world of work. It is also part of the writing life. That proximity between work, hands, their injuring or severing, and storytelling indicates how writing similarly becomes a form of work that alienates the self from the body. To go back to Dermot McCarthy's assessment of Lane's work as a process of "flesh seeking an escape to spirit through words," we might see instead how words disrupt the flesh, making the body, the written about body, part of the work.

As I come back to those old rogues in northern Alberta who passed through my childhood with such regularity, I see, too, how those hands, fingers, toes, all of those bodies become parts of stories. These were the stories of the men around whom I grew up, the heroic fingers of George Ryga holding up the Athabasca bridge, opening the land to cultivation, operating at the behest of imperial powers elsewhere that dictated that those vulnerable bodies should do the work of the state and that would, in turn, make it possible for someone like me to do the work of interpreting their stories. 


\section{Works CiTED}

Atwood, Margaret. Surfacing. Toronto: McClelland and Stewart, 1972. Print.

Birney, Earle. "David." 15 Canadian Poets x 3. Ed. Gary Geddes. Toronto: Oxford UP, 2001. 54-61. Print.

Carter, Adam. "'How Struggle Roots Itself in Ritual': A Marxist Reading of the Poetry of Patrick Lane." Essays on Canadian Writing 55 (1995): 1-21. Print.

Hoffman, James. The Ecstasy of Resistance: A Biography of George Ryga. Toronto: ECW, 1995. Print.

Lane, Patrick. "For Earle Birney.” Patricklane.ca. Web. 19 Aug. 2016.

---. Passing Into Storm. Vernon: Traumerei Communications, 1973. Print.

---. Red Dog, Red Dog. Toronto: McClelland and Stewart, 2008. Print.

---. Selected Poems: 1977-1997. Madeira Park: Harbour, 1997. Print.

---. There Is a Season: A Memoir. Toronto: McClelland and Stewart, 2004. Print.

---. "To the Outlaw." Western Windows: A Comparative Anthology of Poetry in British Columbia. Ed. Patricia M. Ellis. Vancouver: CommCept, 1977. 209-13. Print.

McCarthy, Dermot. "The Poetry of Patrick Lane." Essays on Canadian Writing 39 (1989): 51-89. Print.

Nichol, bp. "Selected Organs." The Alphabet Game: A bpNichol Reader. Ed. Darren Wershler-Henry and Lori Emerson. Toronto: Coach, 2007. 226-35. Print.

Woodcock, George. Patrick Lane and His Works. Toronto: ECW, n.d. Print.

Kit DobsOn is Associate Professor at Mount Royal University in Calgary, Treaty 7 territory. He is most recently the author of Malled: Deciphering Shopping in Canada (Wolsak and Wynn, 2017). His other books are Transnational Canadas: Anglo-Canadian Literature and Globalization (Wilfrid Laurier UP, 2009); Transnationalism, Activism, Art (edited with Áine McGlynn; U of Toronto P, 2013); Producing Canadian Literature: Authors Speak on the Literary Marketplace (with Smaro Kamboureli; Wilfrid Laurier UP, 2013); and the edited book Please, No More Poetry: The Poetry of derek beaulien (Wilfrid Laurier UP, 2013). He is one of the editors of two forthcoming collections of essays, Dissonant Methods: Undoing Discipline in the Humanities Classroom and All the Feels: Affect and Writing in Canada / Dans tous les sens: Affect et écriture au Canada, both from the University of Alberta Press. He is currently writing about the northern Alberta territories in which his family settled.

kdobson@mtroyal.ca 